\title{
Uterine Corpus Cancer pT2 TNM Finding v6
}

National Cancer Institute

\section{Source}

National Cancer Institute. Uterine Corpus CancerpT2 TNM Finding v6. NCI Thesaurus.

Code C61346.

Uterine corpus cancer with invasion of the cervix without extension beyond the uterus.

(from AJCC 6th Ed.) 